\title{
Exploring the Washback Effects of a High-Stakes English Test on the Teaching of English in Spanish Upper Secondary Schools
}

\author{
Marian Amengual Pizarro \\ University of Illes Balears \\ marian.amengual@uib.es
}

\begin{abstract}
In the past decades, there has been a growing interest in the effects of language tests, especially high-stakes tests, on teaching and learning referred to as 'washback'. In fact, high-stakes tests have started to be exploited to reform instruction and achieve beneficial washback.

This paper focuses on the washback effects of a high-stakes English Test (ET) on the teaching of English. The main goal of this study is to examine the washback effects of the ET on the following aspects of teaching: curriculum, materials, teaching methods, and teaching feelings and attitudes. The study also attempts to discover teachers' perceptions towards the introduction of a speaking and a listening component in the design of the new ET due to be implemented in 2012.

The overall findings, collected from a questionnaire carried out among 51 secondary teachers, indicate that the ET is clearly affecting curriculum and materials. Results also reveal that the ET appears to influence teachers' methodology. Furthermore, most of the teachers believe that the introduction of a speaking and a listening component in the new ET design will help solve the mismatch between the communicative approach they seem to value and the skills so far evaluated in the ET.
\end{abstract}

\section{Introduction}

In educational literature, there seems to be general consensus that tests have washback effects. The term washback refers to the positive or negative influence that tests have on teaching and learning (Hughes, 1989; Alderson and Wall, 1993). Although this educational phenomenon 
has historically been commonly associated with rather more harmful than beneficial effects (Spolsky, 1996; Chapman et al., 2000), in the past decades, tests, particularly high-stakes public tests, have been exploited to promote curricular and pedagogical reform and achieve beneficial washback (Wall and Alderson, 1993; Cheng, 1997, 2005; Wall, 2000; Saif, 2006). Underlying this latter approach there is the assumption that high-stakes tests, namely, tests which are thought to have important consequences for test-takers and other people concerned (Madaus, 1988), can exert a desirable influence on teaching and learning and improve educational practices through reform of examinations (Chapman et al., 2000; McNamara, 2001; Shohamy, 2001). Thus, Weir (1990) claims that tests can be very potent tools for curriculum innovation in language pedagogy. In the same vein, Spolsky(1996) points out that tests are powerful tools that can be manipulated to control and reform instruction. Similarly, advocates of measurement-driven instruction (MDI), promote the use of tests as deliberate washback generating devices and claim that tests are the most cost-effective way of improving education and support good practice (Popham, 1987).

The emphasis on promoting positive washback has also been a major objective of communicative language tests. High-stakes tests have, therefore, been employed to connect tests more closely to communicative teaching. As Green (2007:12) observes: "Tests may be reformed under pressure from teachers to reflect more closely, and so support, desired practices in teaching and learning". Following this line of argument, many researchers (AdairHauck et al., 2006; Choi, 2008; Norris, 2009) advocate that the main aim of testing should be to feed into students' learning and improve performance, not merely evaluate it: "Tests should serve as a nexus to connect classroom based instruction practices and work in tandem" (AdairHauck et al., 2006: 365).

Despite everything that has been said, the manipulation of high-stakes tests to deliberately produce beneficial washback and improve educational practices has not produced conclusive results. Hughes (1988) reported the benefits for learning that the introduction of a new test in Turkey had achieved. However, most recent research in this area has found that language tests affect certain areas of teaching but not others. Thus, language tests seem to be effective in bringing about changes on teaching content but have only limited apparent success on teaching methodology (Alderson and Wall, 1993; Shohamy et al., 1996; Cheng, 2005; Luxia, 2007).

This research study was carried out to shed some light on the washback effects of highstakes tests on different aspects of teaching as well as to examine the extent to which changes in a high-stakes university English test due to be implemented in the near future may reform instruction.

\section{Context of study}

The present study is an extension of a previous investigation (Amengual, 2009) designed to explore the washback effects of the English Test (ET) in the Spanish University Entrance Examination (SUEE). The SUEE is a high-stakes public examination taken annually by millions of secondary-schools graduates at the end of their secondary education in order to 
enrol in a Spanish University. The ET included in the SUEE is a competitive norm-referenced proficiency test whose main purpose is to select and discriminate students as reliably as possible. The results obtained in the ET are consequently of critical importance in students' lives since they are decisive in determining the choice of their future careers.

Given the crucial role of this examination, the manipulation and reform of the ET is believed to achieve beneficial washback and improve education (see Weir, 1990; Spolsky, 1996). The design of the new ET put forward by the Spanish education authorities includes the obligatory evaluation of a speaking and a listening component responding in this way to the universities' concerns about the level of spoken English among undergraduates (Herrera \& Laborda, 2005; Amengual, 2006). This initiative has also been welcomed by many secondary teachers and researchers who criticised past ET examinations for depriving students of crucial opportunities to acquire more productive communicative skills not evaluated by the ET. Moreover, it is generally believed (Amengual, 2009) that preparing students for the ET has a negative impact on the teaching of oral communication since most of the class time is devoted to the teaching of skills featured in the ET. Therefore, it was high time that tests that required students to perform communicative tasks in L2 were developed. The aim of this study was twofold. Firstly, it intended to examine the influence of the English Test, included in the SUEE, on five main teaching aspects: curriculum, materials, teaching methods and teacher's feelings and attitudes. Secondly, it investigated the washback effects associated with the new ET proposal developed by the Spanish education authorities into the Spanish educational system in order to meet the ever-increasing demand for more communicative English tests. Although the initiative has been launched, the design of the new ET is not due to be implemented until 2012 (see REAL DECRETO 1892/2008, de 14 de noviembre, BOE de 24 de noviembre).

\section{Components of the ET}

The ET format is very similar across Spanish universities. Although there might be some slight variations, the ET concentrates almost exclusively on candidates' reading and writing abilities rather than on more communicative language competence models (Canale and Swain, 1980; Canale, 1983; Bachman, 1990). This study is based on the ET taken at the University of the Balearic Islands (UIB). Although the current ET has been slightly modified since the study took place in 2008 , the main components of the test remain practically the same. Thus, the ET consists of four or five questions based on an initial reading passage. The components of the ET at the UIB at the time the study was carried out were the following: a reading passage with four True/False statements (question 1), two open comprehension questions based on the reading passage (question 2), a lexical comprehension section (question 3), a grammar section (question 4) and, finally, an essay which consists of developing a topic related to the subject matter of the initial reading passage (question 5). The final score of the ET adds up to 10 points. Table 1 below shows the different questions found in the ET, the scores attached to each of them, the nature of the questions from the point of view of correction, and the techniques used to evaluate the different questions in the examination. 


\begin{tabular}{|c|c|c|l|}
\hline Item & Score & Type of item & \multicolumn{1}{|c|}{ Techniques } \\
\hline 1 & $0-1$ & Objective & True / False \\
\hline 2 & $0-2$ & Subjective & Comprehension question (Open answer) \\
\hline 3 & $0-1$ & Objective & Matching synonyms \\
\hline 4 & $0-2$ & Objective & Grammar transformation \\
\hline 5 & $0-4$ & Subjective & Non-directed essay \\
\hline
\end{tabular}

Table 1. Components of the ET at the UIB.

\section{Method}

\section{Research questions}

Following the previous investigation carried out in 2007 (Amengual, 2009), the main objectives of the present study were the following:

(1) Firstly, to find out whether the findings regarding teachers' opinions on the washback effects of the ET on different aspects of teaching (i.e. curriculum, materials, teaching methods and teachers' opinions and attitudes) are confirmed or, on the contrary, cannot be supported in this study.

(2) Secondly, to examine teachers' views and feelings towards the inclusion of an obligatory speaking and listening component in the new ET design approved by the Spanish education authorities.

\section{Participants}

In total, $51(\mathrm{~T}=51)$ secondary education qualified teachers took part in the present study. The teachers had been called together to attend the annual meeting that the UIB English coordinator holds at the university. The purpose of this general meeting is to inform heads of English departments in upper secondary schools about the format and structure of the ET as well as to let them know about any potential modification in the ET design. Since the teachers came from 51 different institutions around the island, representativeness is ensured.

In the initial study carried out in 2007 (Amengual, 2009), 17 teachers $(\mathrm{T}=17$ ) who had participated as raters in 2007 SUEE administration at the UIB were involved in the research investigation.

\section{Data Collection}

A teacher's questionnaire based on a preliminary one (see Amengual, 2009) was employed to collect data. The questionnaire was administered and completed by 51 secondary teachers and consisted of four main sections which comprised overall twenty-five, mostly closed-ended questions. As noted above, the questionnaire was intended to explore teachers' views on the influence that the ET was having on the following classroom-related areas: curriculum (items 1-6), materials (items 7-10), teaching methodology (items 11-17) and teachers' feelings and 
attitudes (items 18-26) as well as teachers' opinion towards the design of the new ET. The results and discussion for each of these aspects are presented in the following sections below.

\section{Results and discussions}

\section{Curriculum}

The first section of the questionnaire was comprised of 6 questions (items 1-6) which attempted to investigate the effect that the ET was having on different aspects of teaching associated with the curriculum. The questions also aimed at examining the influence that the new ET design was supposed to have on teachers' behaviour in class. The following curriculum aspects of teaching were examined here:

1) The time devoted to the preparation of the students for the ET.

2) The teaching of the contents and skills included in the ET.

3) The teaching of skills not included in the ET and the amount of time devoted to teaching them.

4) The main skills in the ET that deserved most attention in the English lessons.

5) The main skills in the design of the new ET that were bound to deserve most attention.

6) The average number of students that teachers had in their lessons.

In order to answer the first question, teachers were required to use a 1-5 Likert-type scale ranging from 'a lot of time' to 'hardly any time'. Table 2 below reports the comparative findings of teachers' responses associated with the curriculum in the 2007 and the 2008 questionnaire data. As can be observed, in the present study (i.e. ET 2008), the majority of teachers $(86.3 \%)$ reported spending 'a lot of time' $(41.2 \%)$ or 'quite a lot of time' $(45.1 \%)$ to prepare students for the ET. Only $13.7 \%$ of the teachers admitted to spend 'enough time'. These results are similar to the ones obtained in 2007 (i.e. ET 2007), although the present study shows a higher percentage of responses on the positive end of the scale $(86.3 \%$ vs.70.5\%). Apparently, the tendency is to allocate most of the classroom time to the preparation of students for the ET. This is a clear indication that tuition is geared to ensuring that students pass this examination. No negative answers (i.e. 'little time' or 'hardly any time') were found on the negative end of the scale in either study.

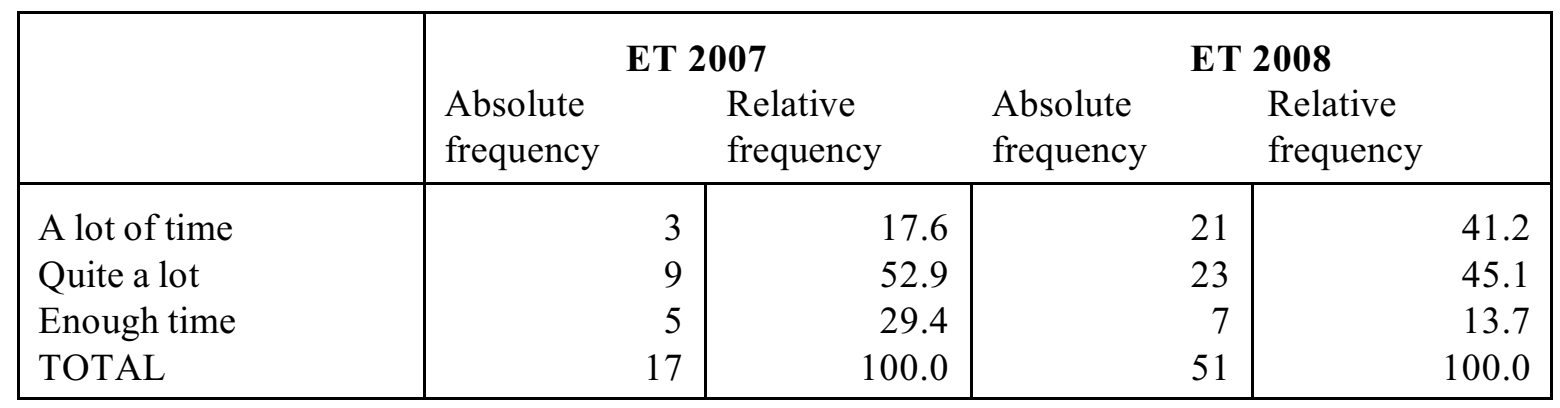

Table 2. Time devoted to the preparation of the ET. 
With respect to the teaching of contents and skills included in the ET (items 2, 3 and 4 of the questionnaire), the overall number of teachers with no exception indicated that all the skills required in the ET were practised in class. Furthermore, as Table 3 shows, some teachers (21.6\%) clearly admitted not paying 'any time' at all to the practice of skills not included in the ET. This finding provides one more example that the ET has a major influence on the content of teaching since it restricts and limits the range of the curriculum to only those aspects most likely to appear in the examination (see Smith, 1991; Gipps, 1994).

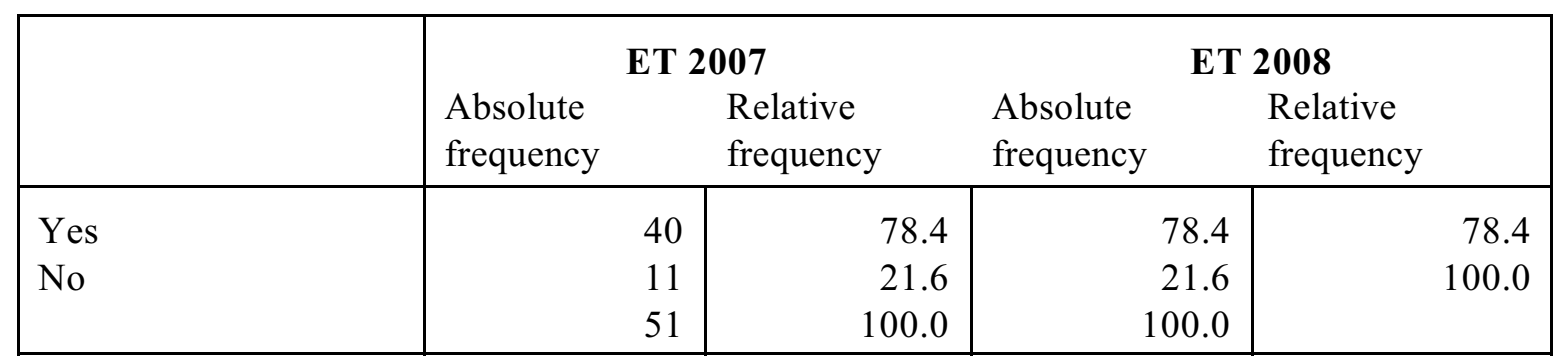

Table 3. Teaching of skills not included in the ET.

It is also worth noting the fact that although the majority of teachers $(78.4 \%)$ in Table 3 reported paying some attention to the skills not evaluated in the ET, Table 4 below shows that only $2 \%$ of the teachers indicated spending more than $50 \%$ of class time to the practice of these skills. In fact, $51 \%$ of the teachers reported spending less than the third part of their course time working with them and $27.5 \%$ of the teachers admitted to spend less than half of their course time to practising them. Moreover, if we compare the data obtained in 2007 and 2008 (ET 2007 vs. ET 2008), it can be observed that the tendency seems to be toward a decrease in the amount of time devoted to the teaching of skills not featured in the ET. These results find support for the fact that the ET considerably reduces the time available for instruction. Thus, there is no denying that virtually all the teachers are conditioned by the ET and, accordingly, they teach to the test. This finding is in line with others that found that when high-stakes are involved, "'teaching to the test' becomes almost unavoidable" (Bachman and Palmer, 1996: 33). Davies (1990) also considers any attempt to prevent teaching to the test futile.

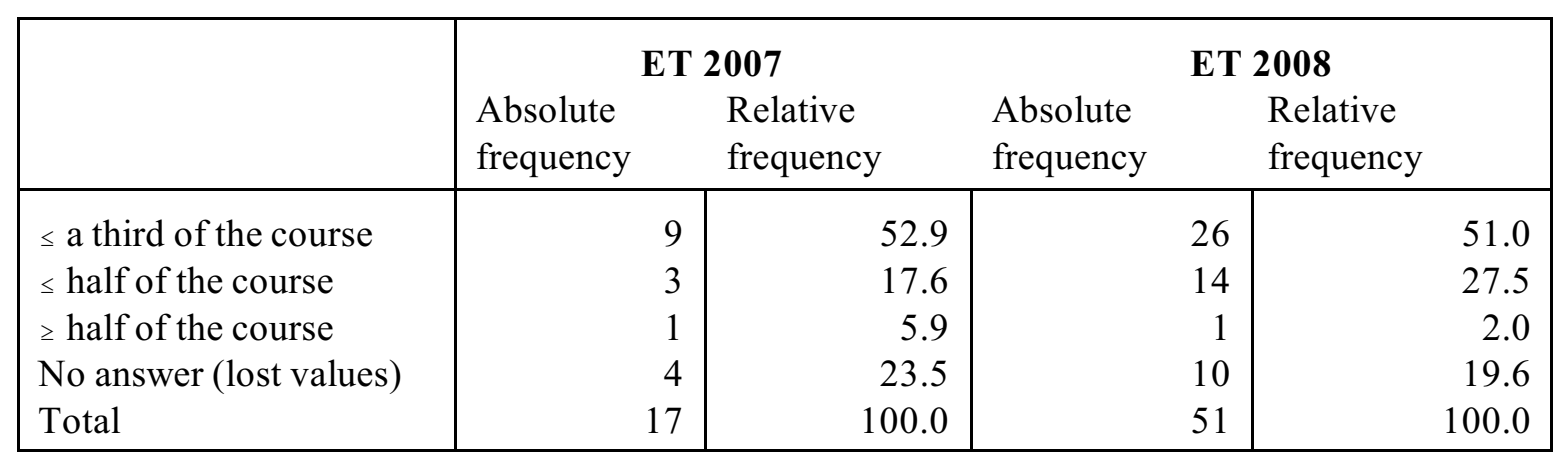

Table 4. Time devoted to the teaching of skills not included in the ET. 
With regard to the amount of class time devoted to the teaching of each specific skill included in the ET (Table 5), it was found that the three parts of the ET that received most attention in the present study (ET 2008) were as follows: 'essay' (98.1\%), followed by 'grammar section' (96.1\%), 'reading comprehension' (74.5\%), and finally 'true/false questions' (15.7\%) and 'vocabulary' (7.8\%). The previous study (ET 2007) yielded similar results with the only exception that 'grammar' and 'reading comprehension' were equally ranked in order of importance, probably, due to the fact that both questions receive the same weight in the examination. As can be observed, the 'essay' was the question which was paid most attention in the two studies (ET 2007 and ET 2008). Since the 'essay' is the question in the ET carrying the most weight, these results were rather predictable. According to William (1996) and Cheng (1997), this outcome is perfectly reasonable since teachers rightly consider it their duty to prepare students to achieve the higher marks in the test. It seems evident that teachers teach narrowly to what is tested and focus on the aspects that are assured to bring about the best results in the ET.

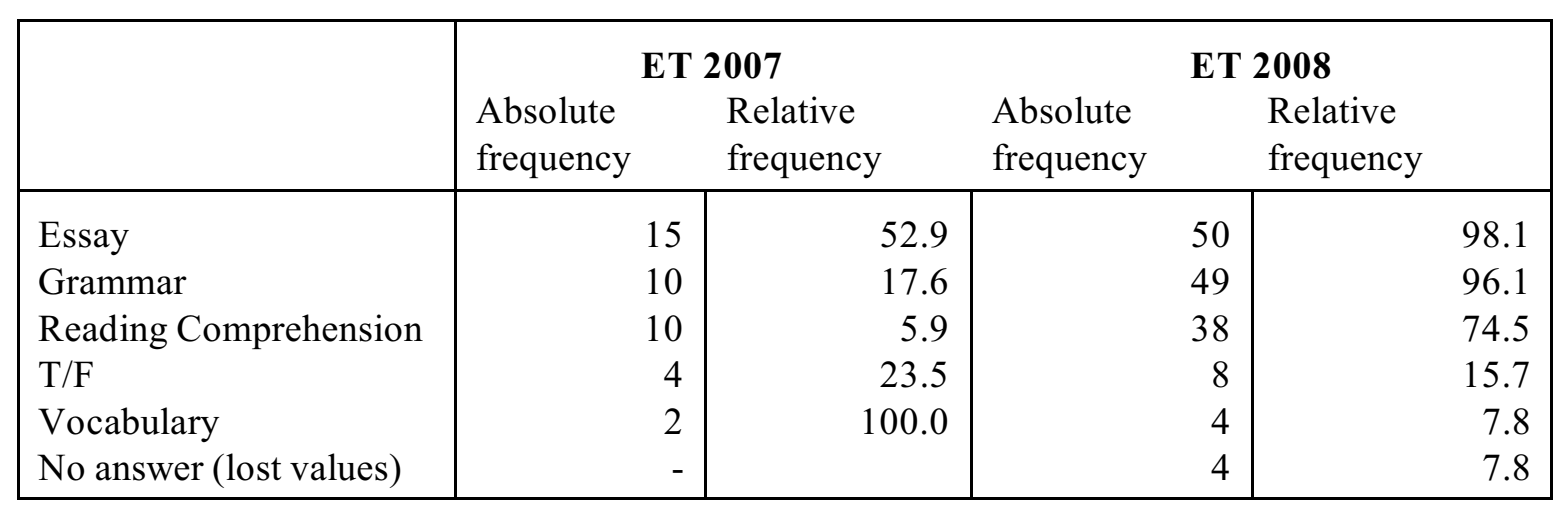

Table 5. Time devoted to the teaching of main skills in the ET.

Table 6 below shows the amount of class time that teachers expect to spend on the teaching of the four main skills included in the new ET (i.e. listening, speaking, reading and writing). As can be seen, the great majority of teachers agreed that they would pay the most attention to speaking (96.1\%) and listening (92.2\%), that is, the two new skills due to be evaluated in the design of the new ET. This outcome appears to support the underlying assumption that speaking and listening will be taught and paid more attention to in class as a result of being included in the ET. Furthermore, the new ET format will enable teachers to reduce the gap that seems to exist between classroom communicative activities and the skills that are evaluated in the test.

\begin{tabular}{|l|r|r|}
\hline & $\begin{array}{l}\text { Absolute } \\
\text { frequency }\end{array}$ & \multicolumn{2}{|c|}{$\begin{array}{l}\text { Relative } \\
\text { frequency }\end{array}$} \\
\hline Listening & 47 & 92.2 \\
Reading & 1 & 2.0 \\
Speaking & 49 & 96.1 \\
Writing & 2 & 3.9 \\
No answer (lost values) & 3 & 5.8 \\
\hline
\end{tabular}

Table 6. Time devoted to the main skills included in the new ET. 
Apparently, one of the main concerns regarding the teaching of oral skills seems to be related to class size (item 6 of the questionnaire). Thus, most of the teachers in this study (70.6\%) admitted having to cope with large classes (between 21 and 40 students per class). Only $3.9 \%$ of the teachers reported having less than 5 students per class and $25.5 \%$ indicated they had between 15 and 20 students per class.

\section{Materials}

The four questions included in the second section of the questionnaire (items 7 to 10) were designed to investigate the influence of ET on the materials used in the English lessons. The following issues were considered here:

1. The use of exam-related materials in class and the main types of materials being used.

2. The time factor associated to the use of exam-related materials.

3. The availability of exam-related materials in teachers' institutions.

4. No availability of exam-related materials as a main concern.

As far as the use of materials is concerned (item 7 of the questionnaire), the majority of teachers $(96.1 \%)$ in this study claimed that they used exam-related materials to prepare students well for the ET. As can be observed (Table 7 below), the most widely used materials in the present study (ET 2008) were the following: past papers $(90.2 \%)$ and textbooks (90.2\%), followed by exam-like materials that imitate the format of the ET (74.5\%) and selfmade materials $(68.6 \%)$ that also reflected the specific skills evaluated in the ET on the assumption that this will help students achieve better results. The 2007 questionnaire data show similar results to those obtained in 2008, although in the 2007 ET teachers indicated making a greater use of self-made materials rather than parallel exam forms ranking these in third position in order of importance.

\begin{tabular}{|l|r|r|r|r|}
\hline & \multicolumn{2}{|c|}{ ET 2007 } & \multicolumn{2}{c|}{ ET 2008 } \\
& $\begin{array}{l}\text { Absolute } \\
\text { frequency }\end{array}$ & $\begin{array}{l}\text { Relative } \\
\text { frequency }\end{array}$ & \multicolumn{1}{l}{$\begin{array}{l}\text { Absolute } \\
\text { frequency }\end{array}$} & \multicolumn{2}{l|}{$\begin{array}{l}\text { Relative } \\
\text { frequency }\end{array}$} \\
\hline Past papers & 16 & 94.1 & 46 & 90.2 \\
Textbooks & 14 & 82.4 & 46 & 90.2 \\
Parallel exam forms & 9 & 52.9 & 38 & 74.5 \\
Self-made materials & 13 & 76.5 & 35 & 68.6 \\
\hline
\end{tabular}

Table 7. Most popular exam-related materials.

As already found in the $2007 \mathrm{ET}$, the data revealed a relationship between the proximity of the ET and the use of test-related materials. Thus, the majority of teachers admitted that they relied more heavily on exam-related materials as the test date approached. This outcome is supported by previous investigations such as Green's (2007: 25) that indicate that "the intensity of washback is likely to be seasonal", that is, it increases as the test date gets closer (Bailey, 1999; Spratt, 2005). 
Finally, most of the teachers $(86.3 \%)$ explained that they had access to ET support materials in their respective institutions (item 9 of the questionnaire). Interestingly, the great majority of teachers $(60.8 \%)$ showed some concern for regarding the possibility of being illequipped and having no access to support materials to get students fully prepared for the new ET (item 10 of the questionnaire). It appears that the pressure involved in preparing students for the ET leads teachers to focus most of their teaching ensuring that the materials used in class match the expectations of the examination in order to help students achieve higher test scores.

\section{Methodology}

In order to examine the potential effects of the ET on teaching methods, teachers were asked to respond to seven questions of the questionnaire (items 11 to 17). These questions dealt with different aspects associated with teachers' methodology as shown below:

11) The influence of the ET on teaching methods and the main classroom elements affected by it.

12) The use of a different teacher's methodology in case students were not required to sit the ET.

13) The influence of the ET on students' communication and oral production in class.

14) The expected influence of the new ET on students' communication and oral production in class.

15) The influence of the ET on students' listening comprehension in class.

16) The expected influence of the new ET on students' listening comprehension in class.

17) The expected influence of the new ET on teachers' methodology.

With regard to the first question (item 11 of the questionnaire), the majority of teachers $(92.2 \%)$ claimed that the format of the $2008 \mathrm{ET}$ influenced their method of teaching. Table 8 below reports the comparative findings of the main classroom aspects influenced by the ET in the ET 2007 and the ET 2008. As can be observed, the two main aspects affected by the 2008 examination (ET 2008) were 'tasks' (68.6\%) and 'classroom interaction' $(54.9 \%)$, followed by 'content' (39.2\%), and finally 'classroom atmosphere' $(17.6 \%)$, which seemed to be the least affected classroom-related aspect. Again, there does not seem to be a great deal of discrepancy between the results found in both studies (ET 2007 vs. ET 2008), although in the $2007 \mathrm{ET}$ 'content' rather than 'interaction' was ranked second in order of importance.

\begin{tabular}{|l|r|r|r|r|}
\hline & \multicolumn{2}{|c|}{ ET 2007 } & \multicolumn{2}{c|}{ ET 2008 } \\
& $\begin{array}{l}\text { Absolute } \\
\text { frequency }\end{array}$ & \multicolumn{1}{c}{$\begin{array}{l}\text { Relative } \\
\text { frequency }\end{array}$} & $\begin{array}{l}\text { Absolute } \\
\text { frequency }\end{array}$ & \multicolumn{2}{c|}{$\begin{array}{l}\text { Relative } \\
\text { frequency }\end{array}$} \\
\hline Tasks & 14 & 82.4 & 35 & 68.6 \\
Interaction & 9 & 52.9 & 28 & 54.9 \\
Content & 10 & 58.8 & 20 & 39.2 \\
Class atmosphere & 5 & 29.4 & 9 & 17.6 \\
\hline
\end{tabular}

Table 8. Main classroom aspects affected by the ET. 
In the same vein, it was found that most of the teachers $(80.4 \%)$ indicated that they would change their methodology and teach in a different way if they were not bound by the ET (item 12 of the questionnaire). The main reason teachers reported was that they could devote hardly any time to the practise of students' oral production due to the time pressure associated with the practice of the skills and tasks evaluated by the ET. In light of these results, it is evident that the requirements of the ET conflict with the communicative methodology teachers seem to value. Therefore, the ET reduces the freedom of teachers to use methods that are believed to be incompatible with the format of the ET. Furthermore, the majority of teachers $(94.1 \%)$ explained that students' oral production was clearly affected by the ET (item 13 of the questionnaire) since all the tasks and exercises done in class were test-related.

In order to find out whether these results were statistically significant the Chi-square test was run. As can be seen from Table 9 , the data revealed a significant relationship $\left(X^{2}=4.478\right)$ at $p<0.05$ between these two variables, that is, the use of a different teaching methodology (item 12 of the questionnaire) and the influence of the ET on the practice of oral communication in class (item 13 of the questionnaire). In other words, the use of a different teacher's methodology is clearly related to the influence of the ET on students' oral communication in class. Therefore, we have to reject the null hypothesis (Ho) that establishes that these two variables are independent and therefore there is no association between them. Moreover, most of the teachers $(84.3 \%)$ believe that the introduction of the new ET will increase the amount of time devoted to the teaching and practice of students' oral skills (item 14 of the questionnaire). In light of these results, it is reasonable to suggest that the introduction of an oral component in the new ET format will encourage teachers to promote students' oral production in class making the English lessons more communicative.

\begin{tabular}{|l|r|r|r|}
\hline & \multicolumn{3}{|c|}{ Value } \\
& \multicolumn{1}{|c|}{ dif. } & \multicolumn{1}{c|}{$\begin{array}{l}\text { Asymp. Sig. } \\
\text { (2-sided) }\end{array}$} \\
\hline Pearson Chi-square & $4.478(\mathrm{a})$ & 1 & .034 \\
Likelihood Ratio & 3.409 & 1 & .065 \\
Linear-by-Linear Association & 4.390 & 1 & .036 \\
N of Valid Cases & 51 & & \\
\hline
\end{tabular}

(a) 2 cells (50.0\%) have expected count less than 5 . The minimum expected count is .59

Table 9. Chi-square results for teachers' methodology and practice of oral communication in class.

Similarly, most of the teachers in this study (76.5\%) admitted that students' listening comprehension was also affected by the ET (item 15 of the questionnaire). Accordingly, teachers (78.4\%) believed that the inclusion of a listening component in the new ET would increase students' listening practice in class.

The Pearson correlation below (see Table 10) allows us to establish the strength of the relationship of these latter variables. As can be observed, results show a high significant correlation at $p=0.01$ between the increase of speaking and listening practice $(0.845)$ as a result of the introduction of these two components in the new ET design. These findings indicate that the new ET design is supposed to have a positive washback effect on the teaching 
of speaking and listening since it will promote the practice of these skills so far neglected in class.

\begin{tabular}{|c|c|c|c|c|c|}
\hline & & $\begin{array}{l}\text { Effect on oral } \\
\text { communication }\end{array}$ & $\begin{array}{l}\text { Increased oral } \\
\text { communication }\end{array}$ & $\begin{array}{l}\text { Effect on } \\
\text { listening }\end{array}$ & $\begin{array}{l}\text { Increased } \\
\text { listening } \\
\text { practice }\end{array}$ \\
\hline \multirow[t]{3}{*}{$\begin{array}{l}\text { Effect on oral } \\
\text { communication }\end{array}$} & $\begin{array}{l}\text { Pearson } \\
\text { Correlation }\end{array}$ & 1 & .164 & .272 & .115 \\
\hline & Sig. (2-tailed) & & .259 & .056 & .434 \\
\hline & $\mathrm{N}$ & .434 & .434 & .434 & .434 \\
\hline \multirow[t]{3}{*}{$\begin{array}{l}\text { Increased oral } \\
\text { communication }\end{array}$} & $\begin{array}{l}\text { Pearson } \\
\text { Correlation }\end{array}$ & .164 & 1 & -.052 & $.845^{* *}$ \\
\hline & Sig. (2-tailed) & .259 & & .724 & .000 \\
\hline & $\mathrm{N}$ & 49 & 49 & 49 & 48 \\
\hline \multirow[t]{3}{*}{$\begin{array}{l}\text { Effect on } \\
\text { listening }\end{array}$} & $\begin{array}{l}\text { Pearson } \\
\text { Correlation }\end{array}$ & .272 & -.052 & 1 & -.092 \\
\hline & Sig. (2-tailed) & .056 & .724 & & .535 \\
\hline & $\mathrm{N}$ & 50 & 49 & 50 & 48 \\
\hline \multirow[t]{3}{*}{$\begin{array}{l}\text { Increased } \\
\text { listening practice }\end{array}$} & $\begin{array}{l}\text { Pearson } \\
\text { Correlation }\end{array}$ & .115 & $.845^{* *}$ & -.092 & 1 \\
\hline & Sig. (2-tailed) & .434 & .000 & .535 & \\
\hline & $\mathrm{N}$ & 48 & 48 & 48 & 48 \\
\hline
\end{tabular}

** Correlation is significant at the 0.01 level (2-tailed).

Table 10. Correlations between the new ET design and the practice of speaking and listening.

A final consideration was to examine the expected influence of the new ET on teachers' methodology. Results indicate that the great majority of teachers $(82.4 \%)$ believe that the format of the new ET will affect their methodology (item 17 of the questionnaire). The main reasons put forward by teachers are that they will have to allocate time to practise speaking and listening to ensure that students do well in the ET. Table 11 below shows the Chi-square test for significance of these two variables: the influence of the ET on current teachers' methodology (item 11 of the questionnaire) and the expected influence of the ET on future teachers' methodology (item 17 of the questionnaire). Results reveal a significant relationship between these two latter variables $\left(X^{2}=10.120\right.$ at $\left.p<0.05\right)$. Therefore, we have to reject the null hypothesis (Ho) that establishes that there is no association between the ET and teachers' methodology. On the contrary, the high $\mathrm{X}^{2}$ value shows that the ET is definitely related to the teachers' current and future methodology. Therefore, the perception that washback has little 
apparent impact on teaching methodology (Cheng, 2005) is not fully supported by these findings.

\begin{tabular}{|l|r|l|r|}
\hline & \multicolumn{2}{|c|}{$\begin{array}{l}\text { Asymp. Sig. } \\
\text { (2-sided) }\end{array}$} \\
\hline Palue & \multicolumn{1}{|c|}{ dif. } & .001 \\
Likelihood Ratio & $10.120(\mathrm{a})$ & 1 & .007 \\
Linear-by-Linear Association & 7.347 & 1 & .002 \\
N of Valid Cases & 9.900 & 1 & \\
\hline
\end{tabular}

(a) 2 cells $(50.0 \%)$ have expected count less than 5 . The minimum expected count is .70

Table 11. Chi square results for the use of current and future teachers' methodology.

\begin{tabular}{|c|c|c|c|c|c|}
\hline & $\begin{array}{l}\text { Absolute } \\
\text { frequency } \\
\text { Positive } \\
\text { answers }\end{array}$ & $\begin{array}{l}\text { Relative } \\
\text { frequency } \\
\text { Positive } \\
\text { answers }\end{array}$ & $\begin{array}{l}\text { Absolute } \\
\text { frequency } \\
\text { Negative } \\
\text { answers }\end{array}$ & $\begin{array}{l}\text { Relative } \\
\text { frequency } \\
\text { Negative } \\
\text { answers }\end{array}$ & TOTAL \\
\hline $\begin{array}{l}\text { The SUEE is useful and } \\
\text { necessary }\end{array}$ & 38 & 74.5 & 8 & 15.7 & 46 \\
\hline $\begin{array}{l}\text { Teachers' satisfaction with the } \\
\text { new ET design }\end{array}$ & 28 & 54.9 & 18 & 35.3 & 46 \\
\hline $\begin{array}{l}\text { The new ET will be more } \\
\text { valid }\end{array}$ & 36 & 70.6 & 10 & 19.6 & 46 \\
\hline $\begin{array}{l}\text { The new ET will be more } \\
\text { reliable }\end{array}$ & 25 & 49.0 & 21 & 41.2 & 46 \\
\hline $\begin{array}{l}\text { SS will achieve a better } \\
\text { overall communicative } \\
\text { competence due to the } \\
\text { introduction of the new ET }\end{array}$ & 36 & 70.6 & 10 & 19.6 & 46 \\
\hline $\begin{array}{l}\text { Teachers' self-preparation to } \\
\text { cope with the demands of the } \\
\text { new ET }\end{array}$ & 38 & 74.5 & 11 & 21.6 & 49 \\
\hline $\begin{array}{l}\text { Specific courses for teachers } \\
\text { will be necessary to prepare } \\
\text { SS well for the new ET }\end{array}$ & 26 & 51.0 & 24 & 47.1 & 50 \\
\hline
\end{tabular}

Table 12. Teachers' feelings and attitudes towards the ET. 


\section{Attitude}

The effects of the ET on teachers' feeling and attitudes were also investigated by examining teachers' responses to questions 18 to 26 in the fourth section of the questionnaire. The view teachers have on the ET should necessarily be considered here since their opinion can influence the way they teach and prepare students for the test. The questions explored the following aspects related to this last issue:

18) Teachers' views on the Spanish University Entrance Examination (SUEE) as a whole.

19) Teachers' level of satisfaction towards the new ET design.

20) The validity of the new ET.

21) The reliability of the new ET.

22) The effect of the speaking and listening components to be included in the ET on students' overall competence in English.

23) Teachers' preparation to face the demands set by the new ET.

24) Teachers' training needs associated with the new ET.

25) Teacher's preferences to teach courses associated with the current ET.

26) Teacher's preferences to teach courses associated with the new ET.

The data (item 18 of the questionnaire) revealed that the majority of teachers (74.5\%) approve of the SUEE as a whole and think that this public examination is a useful tool to discriminate students (see Table 12).

The level of teachers' satisfaction (item 19 of the questionnaire) towards the new ET is also high $(54.9 \%)$. In fact, most of the teachers $(70.6 \%)$ believe that this examination will improve students' overall competence in English as a result of including a speaking and a listening component (item 22 of the questionnaire). As can be observed in Table 13 below, the Chi-square test shows these latter findings are statistically significant $\left(X^{2}=7.940\right.$ at $\left.p<0.05\right)$. That is, teachers' satisfaction is clearly related to the belief that the new ET format will improve students' language ability in English since it will equip students with the necessary skills to be competent in the language.

\begin{tabular}{|l|r|l|r|}
\hline & \multicolumn{3}{|c|}{$\begin{array}{l}\text { Asymp. Sig. } \\
\text { (2-sided) }\end{array}$} \\
\hline Palue & \multicolumn{1}{|c|}{ dif. } & .005 \\
Likelihood Ratio & $7.940(\mathrm{a})$ & 1 & .005 \\
Linear-by-Linear Association & 7.808 & 1 & .005 \\
N of Valid Cases & 7.767 & 1 & \\
\hline
\end{tabular}

(a) 1 cells $(50.0 \%)$ have expected count less than 5 . The minimum expected count is 4.07

Table 13. Chi square results for teachers' satisfaction and improvement of students' competence in English.

With regard to the new ET validity and reliability (items 20 and 21 of the questionnaire respectively), teachers believe that the new ET will be more valid (70.6\%) although scarcely more reliable ( $49 \%$ vs. $41.2 \%$ ), probably due to the fact of having to evaluate the speaking 
component which requires rather subjective marking on the part of the raters (see Table 12 above).

\begin{tabular}{|c|c|c|c|c|c|}
\hline & & $\begin{array}{c}\text { New test } \\
\text { satisfaction }\end{array}$ & $\begin{array}{l}\text { New test } \\
\text { validity }\end{array}$ & $\begin{array}{l}\text { New test } \\
\text { reliability }\end{array}$ & $\begin{array}{l}\text { Students } \\
\text { better } \\
\text { equipped }\end{array}$ \\
\hline \multirow[t]{3}{*}{$\begin{array}{l}\text { New test } \\
\text { satisfaction }\end{array}$} & $\begin{array}{l}\text { Pearson } \\
\text { Correlation }\end{array}$ & 1 & $.605^{*}$ & $.507 *$ & $.407 *$ \\
\hline & Sig. (2-tailed) & & .000 & .000 & .004 \\
\hline & $\mathrm{N}$ & 47 & 44 & 44 & 46 \\
\hline \multirow[t]{3}{*}{ New test validity } & $\begin{array}{l}\text { Pearson } \\
\text { Correlation }\end{array}$ & 164 & 1 & -52 & $.845^{* *}$ \\
\hline & Sig. (2-tailed) & 259 & & 724 & 0 \\
\hline & $\mathrm{N}$ & 49 & 49 & 49 & 48 \\
\hline \multirow[t]{3}{*}{ New test validity } & $\begin{array}{l}\text { Pearson } \\
\text { Correlation }\end{array}$ & $.605^{* *}$ & 1 & $.598 * *$ & $.486^{* *}$ \\
\hline & Sig. (2-tailed) & .000 & & .000 & .001 \\
\hline & $\mathrm{N}$ & 44 & 46 & 45 & 45 \\
\hline \multirow[t]{3}{*}{$\begin{array}{l}\text { New test } \\
\text { reliability }\end{array}$} & $\begin{array}{l}\text { Pearson } \\
\text { Correlation }\end{array}$ & $.507(* *)$ & $.598(* *)$ & 1 & $.571(* *)$ \\
\hline & Sig. (2-tailed) & .000 & .000 & & .000 \\
\hline & $\mathrm{N}$ & 44 & 45 & 46 & 45 \\
\hline \multirow[t]{3}{*}{$\begin{array}{l}\text { Students better } \\
\text { equipped }\end{array}$} & $\begin{array}{l}\text { Pearson } \\
\text { correlation }\end{array}$ & $.415^{* *}$ & $.486 * *$ & $.571 * *$ & 1 \\
\hline & Sig. (2-tailed) & .004 & .001 & .000 & \\
\hline & $\mathrm{N}$ & 46 & 45 & 45 & 47 \\
\hline
\end{tabular}

** Correlation is significant at the 0.01 level (2-tailed).

Table 14. Correlation between teachers' satisfaction, validity and reliability of the ET and improvement of students' language ability.

Furthermore, Table 14 shows high significant correlations at $p=0.01$ between these four variables: teachers' satisfaction towards the new ET, the validity and reliability of the new ET, and the improvement of students' language ability in English as a result of the implementation of the new ET. In other words, the level of teachers' satisfaction towards the new ET is associated with the fact of considering it more valid and reliable, and also to the belief that the ET will equip students with adequate communicative skills. 
Despite everything that has been said, it is also worth noting the fact that there seems to be a moderate number of teachers (35.3\%) who feel unsympathetic towards the design of the new ET (item 19 of the questionnaire, see Table 12 above). This is an important consideration to be made since it reveals how teachers respond differently to innovation in teaching. As Spratt (2005: 24) observes: "It is the teacher who can determine to a greater or lesser extent whether to allow washback to operate". Thus, the reluctance that some teachers show to innovation should definitely be taken into account to ensure the successful implementation of this new examination.

With regard to teachers' self-preparation to be able to adapt themselves to the demands of the new ET (see Table 12 above), the majority of them (74.5\%) felt they were well-prepared to face the new challenges set by this examination and capable of fulfilling its requirements. Nevertheless, $51 \%$ of the teachers believed that some preparation (i.e. exam-related courses) was needed to cope with the new test demands.

Finally, Table 15 indicates teachers' preferences to teach courses related to the ET (items 25 and 26 of the questionnaire). Interestingly, the data show that most of the teachers $(76.5 \%)$ like preparing students for the present ET. However, this percentage decreases when they apply it to the new ET. That is, in spite of the fact of having a more favourable attitude towards the latter examination, teachers $(62.7 \%)$ seem to like it better to prepare students for the current ET than for the new ET. Teachers' level of indifference (i.e. 'I don't mind') is also higher when comparing the new ET format to the present ET format (25.5\% vs. $15.7 \%)$. These are important aspects to consider since benefits are unlikely to be achieved if the new ET poses challenges that teachers are not prepared to meet. Only $7.8 \%$ of the teachers admitted they would rather teach other English courses.

\begin{tabular}{|c|c|c|c|c|}
\hline & \multicolumn{2}{|c|}{ Present ET format } & \multicolumn{2}{|c|}{ New ET format } \\
\hline & $\begin{array}{l}\text { Absolute } \\
\text { frequency }\end{array}$ & $\begin{array}{l}\text { Relative } \\
\text { frequency }\end{array}$ & $\begin{array}{l}\text { Absolute } \\
\text { frequency }\end{array}$ & $\begin{array}{l}\text { Relative } \\
\text { frequency }\end{array}$ \\
\hline I like it & 39 & 76.5 & 32 & 62.7 \\
\hline I don't mind & 8 & 15.7 & 13 & 25.5 \\
\hline I'd prefer to teach other courses & 4 & 7.8 & 4 & 7.8 \\
\hline Lost values & 0 & 0 & 2 & 3.9 \\
\hline Total & 51 & 100.0 & 49 & 96.1 \\
\hline
\end{tabular}

Table 15. Teachers' motivation towards students' preparation for the ET.

\section{Conclusions}

The results of this study contribute further evidence to the fact that the ET has a major influence on different aspects associated with the curriculum, especially with content, which is "an area of high washback intensity" (Cheng, 1997: 50). The data reveal that the content and activities are to a large part adapted and geared in the direction of the test. This is in line with the results of a previous study on the washback effects of the ET in the SUEE (see Amengual, 2009) that found that teachers seemed to spend most of their class time practising the skills featured in the ET and neglecting untested skills and material. This has long had serious 
detrimental effects on the overall communicative competence of Spanish students since the current ET format neither includes a speaking nor a listening component in the examination.

From the results of this study, it is also evident that the ET influences classroom material since teachers make use of test format imitation and test-related material on the assumption that this will bring students success (see also William, 1996; Cheng, 1997; Green, 2007). This study is also in line with others (Hughes, 1988; Smith, 1991; Amengual, 2009) that found that high-stakes tests affect teachers' methodology, which is clearly adapted to the requirements of the test. Thus, the ET format leads teachers to ignore important aspects of the curriculum that are not tested in the examination such as oral communication and interaction in the classroom. Therefore, the ET limits teaching methods and contradicts the principles and practices of most teachers' communicative philosophy. In fact, the majority of teachers reported that they would use more communicative activities and teach in a different way if they were not bound by the ET. This outcome is also supported by the Chi-square results (see Table 9) which indicated a significant relationship between the following variables: the influence that the ET has on the practice of oral skills and the use of a different teaching methodology in case students were not required to sit the ET.

On the basis of these results, it seems reasonable to believe that the introduction of a speaking and a listening component in the new ET format will affect teachers' methodology ensuring that these two skills are taught and practised in class in order to get students fully prepared to pass the test. Correlation results (see Table 10) are also compatible with this assumption since they showed significant high correlations between the expected increase in the amount of speaking and listening practice and the implementation of the new ET. In other words, the new ET will encourage teachers to increase the amount of time and attention given to speaking and listening practice. Furthermore, the Chi-square results (Table 11) yielded a significant relationship between the influence that the ET has on both current and future teacher's methodology. Of course, it cannot be affirmed that the ET is responsible for all methodological decisions. However, the results of this study clearly reveal that the ET affects teachers' behaviour and conditions teachers' methodology.

The introduction of the speaking and listening components in the design of the new ET seems to have finally outweighed the objection that the testing of these skills would violate the test evaluation criterion of practicality. Admittedly, we cannot hypothesize a drastic change in teachers' methodology as a result of the new ET format. Also, the results of this study should be taken with some caution since they rely on self-report data from a questionnaire. Further empirical data is needed to obtain a richer understanding of the nature and scope of the washback effects on teachers' behaviour. An area for further research could involve the direct observation of teachers in class in order to see the extent to which changes in the ET influence teachers' behaviour. Nevertheless, it is believed that the new ET design will be more responsive to the real communicative needs and interests of students in contemporary society helping them to improve their overall communicative competence in English. 


\section{References}

Adair-Hauck, Bonnie, Eileen W. Glisan, Keiko Koda, Elvira B. Swender and Paul Sandrock (2006): "The Integrated Performance Assessment (IPA): Connecting Assessment to Instruction and Learning". Foreign Language Annals 39: 359-382.

Alderson, J. Charles and Dianne Wall (1993): "Does Washback Exist?”. Applied Linguistics 14 (2): 115-129.

Amengual, Marian (2006): “Análisis de la prueba de inglés de Selectividad de la Universitat de les Illes Balears". Ibérica 11:29-59.

. (2009): "Does the English Test in the Spanish University Entrance Examination influence the Teaching of English?". English Studies 90 (5): 582-598.

Andrews, Simmons, John Fulilove and Yama Wong (2002): "Targeting Washback - a Case Study". System 30 (2): 207-223.

Bachman, Lyle (1990): Fundamental Considerations in Language Testing. Oxford: Oxford University Press.

Bachman, Lyle and Adrian Palmer (1996): Language Testing in Practice. Oxford: Oxford University Press.

Bailey, Kathleen M. (1999): Washback in Langue Testing. Princeton, New Jersey: Educational Testing Service.

Canale, Michael (1983): “On Some Dimensions of Language Proficiency”. In J.W. Oller, ed., Issues in Language Testing Research. Rowley, MA: Newbury House, 333-342.

Canale, Michael and Merrill Swain (1980): "Theoretical Bases of Communicative Approaches to Second Language Teaching and Testing”. Applied Linguistics 1 (1): 1-47.

Chapman, David W. and Conrad Wesley Snyder (2000): "Can High Stakes National Testing Improve Instruction: Re-examining Conventional Wisdom". International Journal of Educational Development 20: 457-474.

Cheng, Liying (1997): "How does Washback Influence Teaching? Implications for Hong Kong”. Language and Education 11 (1): 38-54.

. (2005): Changing Language Teaching through Language Testing: A Washback Study. Cambridge: Cambridge University Press.

Choi, Inn-Chull (2008): “The Impact of EFL testing on EFL education in Korea”. Language Testing 25 (1): 39-62.

Davies, Alan (1990): Principles of Language Testing. Oxford: Blackwell.

Davies, Alan, Annie Brown, Cathie Elder, Kathryn Hill, Tom Lumley and Tim McNamara (1999): A Dictionary of Language Testing. Cambridge: Cambridge University Press.

Gipps, Caroline (1994): Beyond Testing: Towards a Theory of Educational Assessment. London: The Falmer Press.

Green, Anthony (2007): IELTS Washback in Context. Preparation for Academic Writing in Higher Education. Studies in Language Testing 25. Cambridge: Cambridge University Press.

Herrera, Honesto and Jesús Laborda (eds.) (2005): Estudios y criterios para una Selectividad de calidad en el examen de inglés. Valencia: Universidad Politécnica de Valencia.

Hughes, Arthur (1988): "Introducing a Needs-bases Test of English Language Proficiency into an English-medium University in Turkey”. In A. Hughes, ed., Testing English for University Study. ELT document 127. England: Modern English Publications, 134-146. . (1989): Testing for Language Teachers. Cambridge: Cambridge University Press. 
Luxia, Qi (2007): "Is Testing an Efficient Agent for Pedagogical Change? Examining the Intended Washback of the Writing Task in a High-stakes English Test in China". Assessment in Education 14 (1): 51-74.

Madaus, George F. (1988): “The Influence of Testing on the Curriculum”. In L.N. Tanner, ed., Critical Issues in Curriculum, Chicago, Illinois: Chicago University Press, 83-121.

McNamara, Tim (2001): "Language Assessment as Social Practice: Challenges for Research". Language Testing 18: 334-339.

Norris, John M. (2009): "Understanding and Improving Language Education through Program Evaluation: Introduction to the special Issue". Language Teaching Research. 13 (1): 7-13.

Popham, W. James (1987): “Two-plus Decades of Educational Objectives”. International Journal of Educational Research 11 (1): 31-41.

Real Decreto 1892/2008, de 14 de noviembre, por el que se regulan las condiciones para el acceso a las enseñanzas universitarias oficiales de grado y los procedimientos de admisión a las universidades públicas españolas (BOE número 283 de 24/11/2008).

Saif, Shahrzad (2006): "Aiming for Positive Washback: A Case Study of International Teaching Assistants". Language Testing 23 (1): 1-34.

Shohamy, Elana (2001): The Power of Tests. Washington DC: National Foreign Language Center.

Shohamy, Elana, Smadar Donitsa-Schmidt and Irit Ferman (1996): “Test Impact Revisited: Washback Effect over Time". Language Testing 13 (3): 298-317.

Smith, Mar Lee (1991): "Put to the Test: The Effects of External Testing on Teachers". Educational Researcher 20 (5): 8-11.

Spolsky, Bernard (1996): "The Examination-classroom Backwash Cycle: Some Historical Cases". In D. Nunan, R. Berry and V. Berry, eds., Bringing about Change in Language Education, Hong Kong: The University of Hong Kong, Department of Curriculum Studies, 55-66.

Spratt, Mary (2005): "Washback and the Classroom: The Implications for Teaching and Learning of Studies of Washback from Exams". Language Teaching Research 9 (1): 5-29.

Wall, Diane (2000): "The Impact of High Stakes Testing on Teaching and Learning - Can this be Predicted or Controlled?" System 28 (4): 499-509.

Wall, Dianne and J. Charles Alderson (1993): "Examining Washback: The Sri Lanka Impact Study". Language Testing 10 (1): 41-69.

Weir, Cyril (1990): Communicative Language Testing. Hemel Hempstead: Prentice Hall.

William, Dylan (1996): "National Curriculum Assessments and Programmes of Study: Validity and Impact”. British Educational Research Journal 22 (1): 129-141. 
APPENDIX

SPANISH UNIVERSITY ENTRANCE EXAMINATION: THE ENGLISH TEST

SEX: $\quad$ Female $\square$
AGE: $\quad 20-30 \square \quad 31-35 \square \quad 36-40 \square \quad 41-50 \square \quad$ Male $\square$
YEARS OF WORKING EXPERIENCE:
less than $5 \square \quad$ between 6 and $10 \square$ between 11 and $20 \square \quad$ more than $20 \square$
WORKING PLACE:
CITY:

\section{SECTION 1. CURRICULUM}

1. How much time do you devote to the preparation of students for the English Test (ET)?
$A \operatorname{lot} \square$
Quite a lot
Enough time $\square$
Little time $\square$
Hardly any time $\square$

2. Do you teach your students the skills and contents that are included in the ET during the academic year?

Yes $\square \quad$ No

3. Do you devote some time to the teaching of the skills and contents NOT included in the ET during the academic year?

Yes $\square \quad$ No $\square$

If so, how much time do you devote to the teaching of the latter?
$\leq$ a third of the course
$\leq$ half of the course
$\geq$ half of the course
$\geq$ two-thirds of the course

4. Tick the THREE most important aspects or questions in the ET to which you devote more time in your lessons.

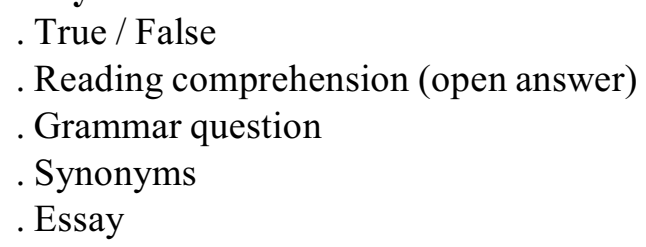

5. Tick the TWO most important aspects or questions in the new ET format to which you think you will devote more time in your lessons.

. Listening

. Reading

. Speaking

. Writing 
6. What is the average number of students do you usually have in your English lessons?

Less than $15 \square \quad$ Between 15 and $20 \square \quad$ Between 21 and $40 \square \quad$ More than 40

\section{SECTION 2. MATERIALS}

7. Do you make use of exam-related materials to prepare students well for the ET?

Yes $\square \quad$ No $\square$

If so, what kind of materials do you use in your English lessons? Tick as many aspects as you consider relevant.

Textbook

Self-made materials

Parallel forms that imitate the format of the ET $\square$

Past papers

8. Do you make greater use of exam-related materials as the ET date approaches?

Yes $\square \quad$ No $\square$

9. Are exam-related materials available in your institution?

Yes $\square \quad$ No $\square$

10. Does the fact of not being able to count on exam-related material for the preparation of students for the new ET worry you?

Yes $\square \quad$ No

\section{SECTION 3. TEACHING METHOD}

11. Do you think the preparation of students for the ET affects the way you teach your students in class?

Yes $\square \quad$ No

If so, what aspects are mainly affected by it? Tick as many aspects as you consider relevant

Subject content

Tasks and exercises

Classroom interaction

Classroom atmosphere

12. Would you use the same teaching method were you not bound by the ET?

Yes $\square \quad$ No

In case the answer is NO, explain why.

13. Do you think students' interaction and oral production in class is affected by the fact of having to prepare students for the ET?

Yes $\square \quad$ No $\square$ 
In case the answer is YES, in what respect?

14. Do you consider the practice of oral communication (i.e. speaking) will increase in class due to the new ET format?

Yes $\square \quad$ No $\square$

15. Do you think the practice of listening was affected by the fact of having to prepare students for the ET?

Yes $\square \quad$ No

In case the answer is YES, in what respect?

16. Do you consider the practice of listening will increase in class due to the new ET format? Yes $\square \quad$ No $\square$

17. Dou you think the new ET format will affect your current teaching method?

In case the answer is YES, in what respect?

\section{SECTION 4. ATTITUDE}

18. Do you consider the Spanish University Entrance Examination (SUEE) useful and necessary as a whole?

19. Are you satisfied with the new ET format recently proposed by the Spanish Government? Yes $\square \quad$ No $\square$

In case the answer is YES, in what respect?

20. Do you think the new ET will be more valid?

Yes $\square \quad$ No

21. Dou you think the new ET will be more reliable?

Yes $\square \quad$ No

22. Do you think students will achieve an overall better language competence in English as a result of including a listening and a speaking component in the new ET?

Yes $\square \quad$ No

Explain your answer

23. Dou you feel prepared to meet the future demands posed by the new ET format? Yes $\square \quad$ No $\square$

In case the answer is $\mathrm{NO}$, in what respect? 
24. Dou you think new specific courses for teachers will be needed to help teachers prepare students well for the new ET?

Yes No

In case the answer is YES, what aspects would you like to deal with in these courses? Explain your answer.

25. Do you enjoy preparing your students for the current ET or would you rather teach students from other academic courses?

I like it $\square \quad$ I don't mind $\square \quad$ I'd prefer to teach other courses $\square \quad$ I don't like it $\square$

26. Do you think you will enjoy preparing your students for the new ET or would you rather teach students from other academic courses?

I like it $\square \quad$ I don't mind $\square \quad$ I'd prefer to teach other courses $\square \quad$ I don't like it $\square$

\section{MANY THANKS!!}

